Article

\title{
Green Buildings in Singapore; Analyzing a Frontrunner's Sectoral Innovation System
}

\author{
Vidushini Siva ${ }^{1}$, Thomas Hoppe ${ }^{2, *}$ and Mansi Jain ${ }^{1}$ \\ 1 Department of Technology and Governance for Sustainability (CSTM), Institute for Innovation and \\ Governance Studies (IGS), Faculty of Behavioral, Management and Social Studies (BMS), \\ University of Twente, P.O. Box 217, 7500 AE Enschede, The Netherlands; \\ vidushini.siva@gmail.com (V.S.); m.jain-1@utwente.nl (M.J.) \\ 2 Policy, Organisation, Law and Gaming (POLG), Department of Multi-Actor Systems (MAS), \\ Faculty of Technology, Policy and Management (TPM), Delft University of Technology, \\ Jaffalaan 5, 2628 BX Delft, The Netherlands \\ * Correspondence: T.Hoppe@tudelft.nl; Tel.: +31-15-278-2783 \\ Academic Editor: Umberto Berardi \\ Received: 29 March 2017; Accepted: 23 May 2017; Published: 31 May 2017
}

\begin{abstract}
The building sector in Singapore consumes up to half of the nation's total energy. The government has therefore been urging the transformation of the industry by targeting $80 \%$ of all buildings to be green-certified by 2030. Thus far, Singapore has done relatively well, and is widely viewed as frontrunner in this respect. This paper addresses the question: what are the benefits and limitations of Singapore's sectoral innovation system in spurring an energy transition in the building sector, in particular by up-scaling the use of green building technology? The Sectoral Innovation Systems (SIS) theoretical framework was used to analyze the Singapore case. Four SIS components were assessed: technological regime, market demand, actor interactions and networks, and institutional framework. The benefits of Singapore's sectoral innovation system identified in the analysis basically concern aspects of all of the four elements of SIS. Particular success factors concerned the launching of an integrated strategy to support green building innovations (i.e., the Green Mark policy scheme), implementing support policies, and setting up test beds. Furthermore, a masterplan to engage and educate end-users was implemented, knowledge exchange platforms were set up, regulations on the use of efficient equipment in buildings were issued, and standards and a certification system were adopted. The results also shed light on key barriers, namely, the reluctance of building users to change their habits, ineffective stakeholder collaboration, and green buildings innovation support coming from the government only. Measures in place have been moderately effective.
\end{abstract}

Keywords: energy transition; green certification; policy; sectoral innovation system; Singapore; green buildings

\section{Introduction}

The building sector is responsible for a significant share of energy-related carbon emissions across the world [1]. Tackling climate change by reducing Greenhouse Gases (GHG) emissions would require significant lowering of GHGs emitted by the construction sector. The "greening" of buildings is an important means which can contribute to this.

As one of the few countries in the world with a 100\% urban population [2], Singapore's building sector consumes up to half the nation's total energy consumption [3]. In 2005, the Building Construction Authority (BCA) of Singapore launched the "Green Mark" scheme in an effort to impel the construction industry towards a more sustainable built environment. According to the BCA, the Inter-Ministerial Committee on Sustainable Development (IMCSD) has set a target of "at least $80 \%$ of the buildings 
in Singapore achieving the BCA Green Mark Certified rating by 2030" [4]. This will require a major transformation to change the way buildings in Singapore are designed, constructed, and operated.

At present, more than ten years after the introduction of the certification scheme, it is estimated that the number of green buildings in Singapore represent about $27 \%$ of the nation's total gross floor area [5]. If this type of growth persists, it is uncertain whether Singapore will be able to meet the IMCSD target. No academic studies have been conducted thus far that evaluate this approach. Therefore, we feel it is necessary to study the current support system for green buildings in Singapore and assess whether it is sufficient to spur the transformative change needed to fulfill the IMCSD target.

This study aims to further understanding of conditions that may spur large-scale energy transition in Singapore's building sector. For this reason, the focus of the analysis in this paper is on Singapore, a country that quite successfully addressed innovations of "green buildings" principles and succeeded to some extent in "greening" its built environment. In this study, the conditions are explored that spurred and hampered innovation in "green buildings", seeking to learn from the approach taken in Singapore.

The main research question posed in this paper is: What are the benefits and limitations of Singapore's sectoral innovation system in spurring energy transition in the building sector, in particular by upscaling the use of green building technology?

In this study, Singapore's innovation system can be characterized as the network of interactions between different elements of the building industry in Singapore-including but not limited to-producers, consumers, institutions, and government actors.

This paper is organized as follows: Section 2 provides a literature review of green buildings across the world and a survey of green buildings practices in Singapore. Section 3 presents the theoretical framework used in this study: the "Sectoral Innovation Systems" (SIS) framework. In Section 4, the research design and methodology are presented. Section 5 presents the results of this study. The results are then discussed in Section 6. Finally, the conclusions are presented in Section 7.

\section{Background}

\subsection{Green Buildings}

Green construction is generally accepted as the "practice of: (1) increasing the efficiency with which buildings and their sites use energy, water, and materials; and (2) reducing building impacts on human health and the environment, through better siting, design, construction, operation, maintenance, and removal-the complete building life cycle" [6]. This requires close cooperation between the multiple stakeholders involved in the development and operation of a building, including the architects, engineers, and end-users.

Typically, green buildings are designed to reduce the negative impacts of the built environment on human health and the natural environment. In Singapore, green buildings tend to have green features that are generally more energy efficient than those in conventional buildings. Some of the key features that might be commonly found in green buildings in Singapore are:

- Improved glass insulation to reduce solar heating through windows;

- Increased natural light, energy efficient lighting devices, and equipment to control lighting;

- Energy efficient cooling plants and ventilation systems for air conditioning;

- Building management systems to monitor and control equipment and optimize energy use; and

- $\quad$ The use of photovoltaic cells [7].

\subsection{Promoting Energy Transition in the Building Sector}

Countries across the world are attempting to promote the development of green buildings. They are trying to set up conditions under which green building innovations can develop, evolve-and when market demand is created-be scaled successfully. They can do this by setting up national innovation systems, that consist of four basic elements; viz., the government, research institutions, 
educational institutions and industry, in which research institutions and industrial firms are assumed to be the centers of the system [8]. However, the approach taken might vary across countries, as studies have shown that the government can also take a central role with just a few specialized firms playing a supporting role, while the majority of firms in the industry act passively [9]. In (national or sectoral) innovation systems (managerial and policy) attention can be awarded to phenomena that are considered the drivers of construction innovation, viz. environmental pressure, technological capability, knowledge exchange, and boundary spanning. These drivers are said to be active at the transfirm, intrafirm, and interfirm levels in the network of organizations in the construction sector [10]. Another important factor to be addressed in setting up green building innovation systems concerns the design and use of demonstration projects in supporting innovations [11].

For instance, the European building sector is undergoing major transformations due to the 2010/31/EU 'Energy Performance of Buildings' Directive (EPBD), which aims at the construction only of nearly-zero-energy buildings after 2020. At present, there is a substantial gap between current practices and the desired performance of buildings, which has to be bridged in a mere three years according to the directive, indicating the urgency of the energy transition of the building sector. Efforts to promote the development of green buildings have therefore increased substantially within countries and across the continent [12].

Studies show that technologies relating to green buildings are continually improving $[13,14]$. Much of such technology is readily available and can be quite cost effective, especially when considered over a longer time period to realize the benefits. Many studies demonstrate the economic and social benefits, and the potential of green buildings [15-19]. Nevertheless, progress towards sustainability has been particularly slow in the construction sector (e.g., [20,21]).

A fair amount of researchers have sought to identify the barriers that prevent the widespread uptake of green buildings [21-25]. In some cases, the adoption of green buildings has encountered considerable resistance due to the risks involved, as buildings are usually expensive and must stand for a long time [26]. Other studies show that economic and knowledge factors are important barriers to adoption (cf. [27]), as are social and psychological barriers [19].

Albino and Berardi [12] suggest that temporary relationships between the companies working on a single building project lead to a failure to develop sustainable construction principles [28-30]. They may even result in sustainable construction issues loosing priority on project agendas, which in turn might lead to poor sustainable performance of buildings when realized [31,32]. This can be related to the main building developers and suppliers involved in a building project being hesitant to invest in green technology as the financial benefits end up benefiting the end-users, and not themselves [33,34]. Although investment in sustainable construction, and more specifically in energy efficiency, is evident from a technical and economical point of view, business firms (but also public organizations) often do not undertake the necessary investment. This is also known as the "efficiency paradox" [35].

A study by Vermeulen and Hovens [20] revealed that end-users of buildings are often the final decision makers regarding the adoption of green building technology. They display a lack of knowledge of the perceived economic benefits of adopting new green building innovations, which poses a substantial barrier. Another study (also in the Netherlands: [21]) identified some of the key barriers that prevented the sustainable transition of the Dutch housing sector. They include poor demand for energy innovations, a fragmented knowledge base, and poor regulatory design.

Even in Sweden, where renewable energy sources account for more than half of the nation's energy production [36], several barriers were noted impeding the adoption of low energy buildings. One of the key barriers, as discovered in a study by Persson and Grönkvist [37], was risk aversion. Consumers prefer to choose experienced and proven technologies over new technologies. This is apparently so even when cheaper alternatives are available [27].

Across the world, retrofitting projects have tended to be hard to implement (when compared to the construction of new buildings) [23], and increased difficulties are experienced when introducing green and energy saving technologies in households [12]. 
In multiple studies, it was observed that retrofitting projects carry a huge risk in that the benefits, both energetic and monetary, will not be realized for many years after the work has been completed [38-40].

In 2009, Germany introduced an updated version of the "EnEV" (additional energy saving regulation), which mandates minimum standards for all new residential and non-residential buildings. This version contains stricter regulations for new buildings and buildings subject to refurbishment, and should therefore lead to improved energy efficiency in the German building sector. These measures have helped to make the results of green initiatives more transparent and accessible, which helps potential building buyers and tenants to make better informed decisions [41]. However, Germany does not rely on mandatory rules only; there are also other incentive schemes. One of these is by the "KfW bank", which is owned by the government and provides reduced interest rates for buildings with improved energy performance [42].

China can also be viewed as a potential growth market for green buildings. However, its government has been reluctant to incentivize this. The government has tried to promote building energy-efficiency through various policies, the most effective one for China being mandatory administration controls. However, its implementation requires more financial resources and consistent funding, which is at times unavailable [43]. In addition, policy enforcement is considered a problem. Due to complicated and bureaucratic administration, enforcement becomes rather ineffective [44].

A study in Hong Kong-a city with similar characteristics to Singapore in terms of its modernity and urbanization-explored the market readiness and policy implications of green buildings. The study revealed that sufficient technological expertise was available. Surveyed experts stated that legislation was considered important, stressing (and citing) the efforts made by the government [45]. Financial bonuses seemed to be the most sought-after incentive for building developers. One way to do this is through tax exemption. For example, the city of Baltimore in the USA offers tax credits for all new residential constructions that qualify for the minimum LEED Silver certification [46].

\subsection{Green Building Rating Tools around the World}

Several different types of assessment tools and certification schemes have been developed around the world to rate green (and monitor) buildings, such as LEED (US), BREEAM (UK), GBCA (Australia), Green Mark (Singapore), DGNB (Germany), CASBEE (Japan), and Pearl Rating System (Abu Dhabi). All these schemes are voluntary. They have been developed by local green building councils, and accredited by commissioned professionals. The World Green Building Council has been established as an international network organization for all the various local councils [23].

These schemes often follow a similar pattern in their assessment of different aspects of a building's degree of sustainability. Each scheme usually has a few "grades" of certification. Credits are awarded for different green features that have been integrated into a building or its design, and the total score reveals the "grade" of certification awarded. Schemes also contain different categories according to the building type and usage, e.g., offices, hotels, and hospitals, to ensure a fair comparison and assessment. The rating tools may differ for reasons that have to do with conditions that are specific to the location in which tools were developed (e.g., climate conditions).

\subsection{Green Building Rating Tools in Singapore}

In Singapore, the BCA has adopted the so-called "Green Mark" scheme. It has been described as the tropics' answer to the LEED scheme in the U.S. The Green Mark scheme differs from the aforementioned green building rating tools in three ways:

- It places greater emphasis on energy efficiency;

- It has been tailored for a tropical climate with the cooling of inner spaces using air-conditioning as a key consideration; and 
- It has higher standards of measurement and verification, using more precise instruments to monitor equipment performance [47].

The "Green Mark" scheme was launched in January 2005 to encourage the construction of more environmentally friendly buildings by the Singapore industry. It has been endorsed and supported by a number of ministerial bodies in Singapore, such as the National Environment Agency. According to the BCA, "It provides a comprehensive framework for assessing the overall environmental performance of new and existing buildings to promote sustainable design, construction and operations practices in buildings. It is intended to promote sustainability in the built environment and raise environmental awareness among developers, designers and builders when they start project conceptualization and design, as well as during construction" [47].

The assessment system of the scheme awards points for specific energy efficient and pro-environmental features and practices that can be integrated into building projects and designs. These features must be more sustainable than the normal practice observed in conventional buildings. The total score provides an indication of the environmental friendliness of the building design and operation. Depending on the overall assessment and score, the building will be certified as having met the BCA Green Mark Platinum standard, the GoldPlus, Gold standard, or the Certified rating, with the Platinum certification being the highest [47].

In line with the Green Mark scheme, three strategic "Masterplans" have been rolled out by the BCA since 2005. In 2012, the Building Control Act was updated to include legislation on the certification of buildings. It stated that newly constructed buildings must at least achieve the minimum certification qualification. In 2013, it became mandatory on building owners to submit energy consumption data to the BCA. In 2014, it became mandatory for building owners to conduct periodic energy audits, and achieve the minimum Green Mark certification when updating or retrofitting their cooling system [48].

There is a requirement that Certified Green Mark buildings must be re-assessed every three years to maintain their Green Mark status. Newly constructed and certified buildings will subsequently be re-assessed under the existing building criteria. The initial certification for new buildings will be awarded based on design. However, after one year, assessment will be based on the building's actual performance [47].

\subsection{Promoting Energy Transition in the Singaporean Building Sector}

Although studies of green buildings in Singapore in general have been published [49], such studies tend to focus primarily on evaluating the Green Mark tool or the engineering and architectural aspects of green buildings [50].

In common with government agencies in other countries that seek to green their building sectors, the BCA deploys incentive schemes and initiatives in place. Examples include the "Green Mark Incentive Scheme for Existing Building and Premises" (GMIS-EBP), which co-funds up to 50\% of the retrofitting cost of energy improvements; the "Building Retrofit Energy Efficiency Financing" scheme (BREEF), which helps to underwrite the risk of default on loans from participating financial institutions for implementing new technology; and the Green Mark Gross Floor Area scheme (GM GFA), which grants additional floor area to developers who seek to achieve at least the Green Mark Gold Plus certification. Aside from financial incentives, the BCA also promotes education through media and schools, and coordinates conferences and exhibitions [48].

\section{Sectoral Innovation Systems}

This study is interested in the systemic conditions that spur "green buildings" innovation. An innovation systems approach is warranted because we are not interested only in adoption of innovations as a decision-making process outcome (i.e., [32,51,52]), and we do not seek to explain for a sustainable transition (i.e., by using theories on socio-technical transitions, such as the Multi-Level Perspective [53] or Strategic Niche Management [54-57], although we acknowledge 
that the process of sustainable transition is ongoing in Singapore's building sector [58,59]), or focus on the effectiveness of (individual) support policies (e.g., [60-62]). Due to our interest at the system level, and conditions spurring innovations and the focus of this study on one economic sector (i.e., the built environment) we selected the Sectoral Innovation Systems (SIS) as the main theoretical framework for this study $[21,63,64]$. The framework was previously used to analyze green innovations emerging in domestic construction sectors in other countries (e.g., in the Netherlands [21], and in India [65]). We will now introduce the key concepts of the SIS framework.

Innovation is considered a key condition for fostering structural change. The concept of an innovation system (IS) has been developed to represent and understand the interactions between producers, users, institutions, and governments [66]. Sectoral innovation systems can be described as the collective emergent outcome of the co-evolutionary interactions between the core building blocks of a system or sectoral market $[63,64,67]$.

SIS has four main dimensions; technological regime, market demand, agents, interactions and networks, and the institutional framework (cf. [21]). These dimensions are illustrated in Figure 1.

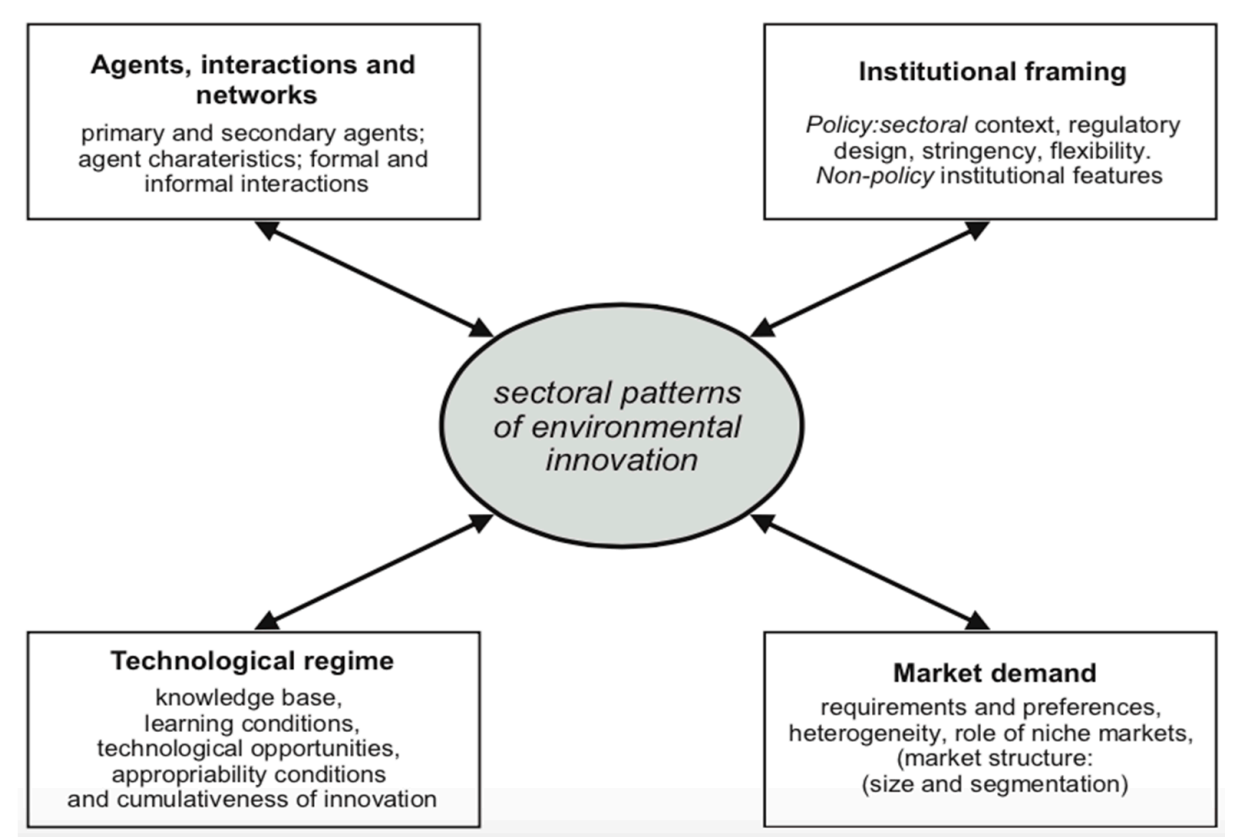

Figure 1. Graphical presentation of the SIS framework.

\subsection{Technological Regime}

Technologies are generally developed in a specific socio-technical context made up of tacit and explicit knowledge, sunk costs, learning conditions, complementarities, and interdependencies [64,68-70].

SIS consists of the following four main aspects.

- Technology: This refers to the new technologies available, the economic feasibility of these new technologies, and the extent to which implementing these new technologies was successful.

- Complementarities and interdependencies: This refers to whether new technology complements or replaces existing technology, and whether any technology is interdependent on another technology. This could be due to the convergence of previously separate products or the emergence of new demand from existing demand.

- Knowledge base: This refers to the extent of knowledge and the methods by which knowledge is disseminated and communicated.

- Learning conditions: This refers to both the internal and external learning processes, and opportunities. 


\subsection{Market Demand}

Demand stems from the preferences of end-consumers, mostly revealed by actual consumer choices. It is valuable to understand the role of end-users in the innovation process by considering their perceptions in adopting certain technology, and how this translates into demand. Users can influence the innovation process, by "experimentally adopting certain technologies, or by gearing the technology to specific demand" [21]. In this study, it refers to the choices building owners and users make with regard to green technology, and how these preferences align with the perceptions of green buildings vis-à-vis the use of conventional buildings. Non-alignment of the two would typically slow down the uptake of green technology and hence, the development of green buildings in the construction sector.

\subsection{Agents, Interactions and Networks}

Agents include individuals as well as organizations, which interact through processes of communication, exchange, cooperation, competition, and command [63]. Agents can be divided into two sub-categories: primary and secondary agents. Primary agents perform core innovative activities, experiments, and capacity building [21]. Secondary agents play a supportive role through knowledge dissemination, financial support, regulations, and counseling.

The level of formal and informal interaction between the agents is also considered. Interactions can take place through platforms for networking and knowledge-sharing. Interactions in actor networks depend on both formal and informal rules. It is essential to understand how well these support innovations and the diffusion of innovations, i.e., green building technology.

\subsection{Institutional Framework}

Institutions include various formal and non-formal rules. Formal rules stem from government legislation, regulation, policies, and initiatives. Informal rules refer to routines, common habits, established practices, laws and standards. All of these shape agents' cognitions and actions, as well as inter-agent interactions $[63,64]$. They also have either a supportive or inhibitory role in the development of green buildings. For example, state laws can help influence the choices agents make through incentives, or even mandate the use of certain technology to ensure its uptake. Conversely, a society's natural habit can inhibit the uptake of technology; a risk-averse society might be hesitant to adopt emerging technology.

\section{Methods}

The research design of the study presented in this paper involves an in-depth case study of Singapore. A case study research design was chosen to investigate the phenomenon of an energy transition in the building sector in detail in its actual context in Singapore (cf. [71]) using a rich set of qualitative data.

Singapore was chosen as the case study for a variety of reasons, the key one being that Singapore is viewed as a frontrunner in the green building movement in the tropics and subtropics. Across Asia, Australia, and Africa, a total of 71 cities have adopted the Green Mark certification scheme. According to the BCA, "In 2010, the consulting firm Solidance had rated Singapore as the first in Asia for its green building policy. In early 2013, research by the McGraw Hill Construction found that out of 62 countries, Singapore was perceived the most highly involved country in the development of green buildings today" [7]. In line with this, and with the IMCSD's goal of having $80 \%$ of green buildings Green Mark certified by 2020, it is therefore valuable and interesting to explore the uptake of green buildings, and its contribution to the energy transition in the Singapore building sector. Singapore can possibly serve as a best practice, from which valuable lessons can be drawn. In terms of case selection on green building innovations in countries the selection of Singapore can be seen as "deviant case" or "extreme case" [72]. Therefore, it is useful to explore the reasons (and conditions) that account for successful green building innovation in this particular country. 


\subsection{Data Collection}

Data collection involved eleven in-depth interviews with stakeholders, secondary data, participation in two conferences, and in a green building site tour. The interviews were divided into two sets: namely those with "primary actors" and those with "secondary actors", following the classification given in the SIS conceptualization. The first set of interviews involved six "primary actors", directly involved with green building projects. This group of interviewees consisted of building developers, architects, technology providers, and building occupants. The interviews provided primary knowledge regarding green building development in Singapore as the actors were directly involved in green building demonstration projects.

The actors mentioned above represent almost all the types of actors in the complex value chain of the building construction sector as identified by World Building for Sustainable Development [73]: viz. capital providers, developers, designers, engineers, contractors, materials and equipment suppliers, real estate agents, owners and users. In addition to the interviews conducted, information on these actors was also gathered using secondary data like reports from governments and other organizations, and information on them obtained via (other) interviewees.

The second set of interviews was conducted with five "secondary actors". This group consisted of government officials, representatives from consultancy agencies, non-profit organizations, and academic researchers. These interviews were done to further understand the dynamics between primary and secondary agents, and the role of the support system in facilitating green buildings niche formation.

Two sets of semi-structured questionnaires were prepared for interviews: one for actors classified as primary agents, and one for actors classified as secondary agents (see Appendix A for the questionnaires). The interviews included questions that were derived from the key theoretical components of the SIS framework. All the interviews were conducted face-to-face, with eight out of eleven having been audio recorded simultaneously. Recorded interviews were then transcribed into reports that were later used for treatment and analysis. Interviewing continued until data saturation was reached. However, interviews with representatives from financial sector actors (i.e., capital providers) were not possible due to non-availability of the selected interviewees at the time of data collection. For information about financial actors, secondary sources were used.

While it is acknowledged that there might be an overlap in the roles of some stakeholders, the study ensured that their roles were addressed separately. This was done by tailoring questions in a manner that was specific to the stakeholder's role in the building construction value chain. For example, when considering market demand, the aspect of consumer choice was phrased differently to different interviewees representing different types of building users. When interviewing a building developer, a question on market demand was raised such as "What choices and preferences do your clients and customers have?". However, to building users, the question was posed differently to better fit their role, i.e., "What preferences do you have in the building you choose to occupy?". Similarly, when institutional support was addressed, questions to a government agency representative were phrased such as "What type of grants do you offer?" or "Have you received feedback from grant receivers on the use of these grants?". To architects questions were raised such as "What types of government grants did you use?", "How do you appreciate them?", and "Do you think they are sufficient?". In this way, actor perspectives could be addressed while interviewing.

Secondary data used concerned news reports, BCA reports, government reports (e.g., on policy, energy savings realized, finance and public surveys), and data from the (academic and professional) literature.

\subsection{Data Analysis}

Qualitative data analysis software ("ATLAS.ti") was used to analyze the data collected. The program assisted in locating, organizing, and visualizing relations amongst the data found in the interview transcripts. A coding scheme was used in the program. The four different aspects of 
the SIS framework were used to assign codes. Their accompanying components, as outlined in the assessment framework, were assigned sub-codes. Quotes extracted from the interview transcripts were clustered under their relevant codes and sub-codes. This permitted systematic, comparative analysis. Both quantitative and qualitative interpretations of the data analysis were made; occurrences of the sub-codes were observed to understand the overall consensus among stakeholders, which was then substantiated by the information provided in the interviews, and other secondary data were then analyzed in detail. Conclusions were then drawn regarding each of the components of the SIS framework.

\section{Results}

This section presents the results, vis-à-vis the components of the SIS framework: (i) technological regime; (ii) market demand; (iii) actors, interactions and networks; and (iv) institutional framework.

\subsection{Technological Regime}

In conceptual terms, a technological regime has four sub-elements, viz.: technology, complementarities and interdependencies, a knowledge base, and learning process. The results with respect to these sub-elements are presented below.

\subsubsection{Technology}

The main green technologies popular in green buildings in Singapore are chiller plant systems, energy-efficient lighting systems, and solar panels. In terms of economic feasibility, all interviewees agreed that the cheapest technology is energy-efficient lighting systems. They usually have a short payback time of less than three years. For the other two, most interviewees admitted that they are rather expensive and have a long payback period (more than five years), but their feasibility is increasing due to advances in technology. High efficiency equipment can actually be made more compact, which has a lower impact on a building's sustainable footprint and increases retail space.

Given the (current) stable economic, political, and geographic conditions in Singapore, investors and companies foresee longevity in their businesses; hence, they foresee larger investments with longer payback periods, in which energy efficient equipment is preferred. They also foresee increased demand for renewable energy technology. Solar panels become more feasible in Singapore when one takes into account government subsidies to encourage the use of renewable energy sources; for instance, the prospect of feed-in tariff implementation.

With regards to chiller plant systems, a promising innovation is in the use of district cooling, in which chilled water is produced centrally and then distributed to buildings nearby via a piping network [74]. In fact, one of the world's largest district cooling plants, commissioned by the government, is housed completely underground at the Marina Bay district in Singapore. It is said that customers using it enjoy savings of more than $40 \%$, an amount that could possibly support over 20,000 home apartment units. The chiller plant system helps to reduce space requirements and starting capital cost. Similar plants are being developed in Singapore, and the success of the Marina Bay plant could potentially pave the way for more cooling solutions [75]. Arguably, district cooling in Singapore could serve as a blueprint for energy efficient cooling of buildings in tropical regions.

Furthermore, the Government of Singapore supports the uptake of green technology through grant schemes promoted by the Green Building Innovation Cluster (GBIC). This scheme provides funding for experimentation, exhibition, and exchange of promising new energy efficiency solutions among industry stakeholders. The schemes have targeted future end-consumers to try and embrace these new technologies.

Despite these positive signs there are some substantial barriers. Aside from cost, eight of eleven stakeholders stated that a barrier was formed by a lack of change in the mindsets of actors throughout the value chain. First, managerial boards within construction companies do not prioritize sustainability. As long as financial growth is achieved and all equipment is operating in good condition, they are not 
motivated to optimize energy efficiency. Second, end-users themselves are averse to change on a broad cultural level. Simulating widespread use of new technology would involve awareness raising and education, while many people-especially the elderly_are unwilling to make efforts to learn how to adjust to, and use new technology. Furthermore, sustainability in itself is perceived an abstract concept with only long-term and far-fetched effects.

\subsubsection{Complementarities and Interdependencies}

Most interviewees indicated that green technology is starting to replace existing technology. With stricter rules from the BCA it is now mandatory for all buildings subjected to any sort of change to meet the minimum level of the Green Mark standard. This level of certification stipulates a certain level of efficiency that can only be achieved with water-cooled chillers. Hence, the use of air-cooled chillers is on the verge of being phased out of the market. The same scenario is prevalent when considering energy efficient lighting. LED lighting is replacing fluorescent and incandescent lighting.

Currently, the use of solar panels is only complementary to the use of conventional electricity from the grid as it is still considered quite expensive. However, it was reported in 2012 that grid parity had been achieved, so that electricity from the grid costs the same as installing and maintaining solar panels [76]. Solar PV companies were adopting the model of "solar leasing" to support consumers in offsetting the high start-up cost of investing in solar panels. Here, the consumers sign a contract to make their roof space available to solar panel companies to generate electricity and to pay for the energy they consume, at a discounted rate of 20 years. Additionally, the Housing and Development Board (HDB) called for a large solar-leasing tender in 2014, under which solar panels would be installed on the rooftops of over 500 residential buildings [77].

Alongside the installation of highly efficient technology, a surge occurred in the demand for building management systems, high sensitivity and high precision sensors that go along with the Green Mark certification. It requires strict monitoring of energy use by building appliances with highly accurate data collection. This serves as a good example of interdependency, as described by Malerba [64], where new demand emerges from existing demand.

\subsubsection{Knowledge Base}

There appears to be sufficient knowledge and technical expertise concerning green buildings and related technology. However, the availability of specific knowledge is limited, and it is kept by consultants and producers, without being shared voluntarily with consumers and end-users. Furthermore, most people look at the BCA guidelines and only implement technology that is (already) explicitly mentioned there. This appears to be related to a lack of knowledge on modeling energy systems in real-life applications. Under the third Masterplan by BCA, actions are undertaken to educate consumers in how to model their energy profile and simulate energy savings. In this way, they can not only implement new technology but also optimize the systems and appliances they already use.

\subsubsection{Learning Process}

There seems to be a substantial effort and openness coming from both primary and secondary agents to ensure coordinated knowledge exchange between projects, stakeholders, and the public. This is usually facilitated by the state government by organizing conferences, workshops, and seminars.

In terms of increasing their knowledge base, project developers in Singapore are keen to educate tenants and end-users. They provide guidebooks in collaboration with the BCA, called the "Green Lease Toolkit on sustainability practices". In 2015, a scheme was launched by BCA to encourage the certification of rental spaces, which would help to increase engagement and education of end-users. Moreover, buildings with high green building performance (typically Green Mark Platinum certified) are given public recognition by the BCA. These buildings are usually open to the public for guided educational tours. 
There also appears to be a need to reorient the production of academic knowledge about green buildings. During one of the interviews, a university professor mentioned that a change is needed in the academic landscape. He argued that there should be more publications on incremental research and studies on actual testbeds and demonstration projects. This would highlight the performance of specific technologies, and opportunities to save energy in real-life practice.

\subsection{Market Demand}

Most of the interviewees ranked cost effectiveness as their highest priority, referring to buildings with low rent, and technology that has more benefits than cost. Technologies with low payback periods were preferred (i.e., under three years). The technologies perceived as the costliest in green buildings concerned energy efficient water-cooled chiller plants, which have payback periods between five to ten years, making them rather economically undesirable for consumers.

Consumers preferred well-established technologies that have proved to work in the past, and generally does not require any new level of knowledge to operate. Most interviewees agreed on the risk-averse nature of the Singaporean market, in which consumers are conservative in their choices and prefer not to be the first to try out experimental, unproven technology. However, some actors are currently taking measures to overcome this problem. For example, at a university, the first steps have been undertaken to implement emerging green building technologies. The site is in the university's own campus buildings (part of a program called "EcoCampus"). This not only allows new technologies to be tested in Singapore (to assess effectiveness, given the climate demands of high temperatures and high humidity conditions), but it also pairs researchers to the equipment to monitor and document the results carefully. Apart from this, the BCA also issued a pilot scheme called "BREEF" (Building Retrofit Energy Efficiency Financing), which helps to counter high upfront costs of investing in new technology by underwriting some of the risks when a company wishes to take out a loan to pay for the technology. These measures were considered effective in reducing risk aversion among investors and project developers.

Most interviewees considered sustainability a secondary (non-prioritized) factor. Typically, companies seek energy efficient measures to enhance their corporate social responsibility standpoint and brand marketing. Interviewees representing construction companies stated that striving to achieve sustainability goals is closely related to health and well-being of their employees. A green building is said to have a better overall office environment in terms of natural lighting, air quality, and comfortable temperature settings. This has also led building users to seek more green office spaces, especially for MNCs with higher financial capital. BCA recently released the Green Mark Portfolio Program, which seeks to certify tenant living spaces (as opposed to entire buildings) and optimize buildings' overall footprints. There is also a Green Lease Toolkit, which serves as a handbook for owners and tenants regarding good practices and sustainability targets.

Although more companies are seeking and using green office spaces, there seems to be a lack of effort on the part of retail space owners. Shopping malls and supermarket owners are opposed to the idea of energy efficiency because it perceived to have a negative impact on their sales. For instance, brightly lit malls with air-conditioning streaming out tend to attract customers. To increase air-tightness and prevent losses (as a solution), a greener mall could be designed having double doors. However, this usually reduces visual marketing and gross floor area. In supermarkets, refrigeration sections for frozen goods tend to be open to increase product visibility and increase sales, leading to extra energy losses. Another problem is related to a lack of legal provisions covering lighting and air-conditioning in shopping malls. However, the BCA recently started to pay more attention to the greening of shopping malls and retail spaces. Some public building managers have stressed that they want to set an example by achieving a higher Green Building performance than is required according to the Green Mark certification.

The BCA also has a role itself as "launching customer". Its headquarter is located in a Green Mark Platinum certified building, which concerns a "lifestyle mall" that combines shopping, residential use, 
and offices, all on the same site. At the time, more shopping malls were subjected to renovation with the aim of gaining a Gold Plus or Platinum rating to maintain competitiveness.

Despite all these efforts, a member of the Business Council for Sustainable Development conveyed that green buildings remain under-valued in the building market. They cannot be rented or sold at a premium, even when they are Green Mark certified. This would result in a lack of demand from investors. To address these and other issues, the BCA introduced a new scheme, called the Green Mark Gross Floor Area incentive scheme (GM GFA), in which buildings can afford increased GFA on the condition that substantial energy efficiency enhancements are made. Furthermore, policy makers are in the process of integrating energy efficiency in the assessment and appreciation of buildings in the scheme, so that energy efficient buildings can attain a higher market value than conventional ones.

\subsection{Actors, Interactions, and Networks}

\subsubsection{Actors}

A wide range of actors are involved in the building construction sector. Primary actors include architects, engineers, consultants, suppliers, technology providers, building owners, building developers, and tenants. Secondary actors include the BCA and other government agencies, green consultants, investors, non-profit organizations and councils, and research institutes (often academic).

Most interviewees agreed that BCA occupies the most influential position, some of them even stating that they are heavily dependent on the BCA. In Singapore, the state government has launched new regulations, and the industry follows its lead in adopting sustainable practices. Singapore tends to follow a top-down approach. When compared to other countries, the Singapore government is perceived to have a greater sense of understanding of what the market requires, which supports the creation of programmes and policies. These programmes and policies create conditions for innovation needed to bring about change in the building sector. Although different stakeholders can provide feedback on the standards, the BCA is said to have the last call and ensure that standards are being met.

\subsubsection{Actor Interactions and Networks}

The national government is very active in trying to forge interaction among the various stakeholders. Eight out of eleven stakeholders acknowledged that the government has done a good job in providing platforms for interaction. In the process of refreshing its masterplan and legislation, BCA calls upon an international panel of experts to provide their feedback and engages stakeholders through consultation sessions to review their plans and standards. However, the matter of who sets the agenda for those meetings is considered of great importance. More often than not, it is the BCA that decides the topic of discussion and it was (only) then, that the industry responds. The interaction between stakeholders proceeded mostly in only one direction; with few initiatives from the industry to approach the BCA. This was perceived to limit the effectiveness of such interactions, when concerns and ideas were not voiced in a multi-participant decision-making process.

Collaboration between stakeholders was regarded by the interviewees as poor. This was related to the absence of an approach using an integrative design. Different stakeholders come in at different stages of building projects, which often leads to a lack of coherence and sub-optimal design. This means that project goals could become diluted due to the temporal involvement of stakeholders. For example, an interviewee revealed that a project could have begun with the goal of installing an energy efficient chiller plant. However, the building developer (typically) splits the tendering process to different suppliers to provide different parts of the chiller system. In the end, its overall performance is neglected in favor of lower costs, and no single stakeholder is able to take responsibility for the integrated performance of the chiller plant.

Another interviewee suggested that a performance-based model could potentially counteract the problem of stakeholders coming in at different stages of the project resulting in communication. Currently, the Green Mark standard only stipulates what level of efficiency must be achieved, and it is 
up to the owner or user of the building to decide how to achieve it. However, a performance-based model could incentivize all parties to come together right from the start of a project, and deliberate how to design and optimize one or more buildings to achieve the desired "Green Building" performance.

\subsection{Institutional Framework}

\subsubsection{Formal Institutions}

The BCA uses several policy instruments and innovative approaches, e.g. grants as financial incentives. The BCA also recently issued a mandate for organizations to reveal energy performance data so that BCA can do more effective benchmarking. Companies performing well are given awards and recognition, which can help them boost their marketing. This has led numerous companies becoming more competitive and to strive for government endorsement. The BCA also approached "underperformers" to raise awareness, and provide information and guidance on how they can improve their energy performance. Besides this, the BCA offers many public education schemes to engage a wider audience.

In terms of effectiveness, six interviewees conceded that the efforts from the government have only been moderately effective, and that goal attainment was mostly related to the implementation and enforcement of strict laws and regulations. The 'Singapore Standards' document published by the government sets out the specifications for the "design, use or performance of materials, products, processes, services and systems" [78]. For instance, only chiller equipment that meet a minimum level of efficiency are allowed entry into the market. Interviewees from industrial parties considered this regulatory stipulation as, "quite demanding".

When considering grants, interviewees view the size of budgets granted as substantial. However, it was suggested that a better benchmarking method is needed to ensure that smaller companies with less financial capital can also benefit from the grants. Currently, they are fairly under-represented in the grant schemes. It was also observed that consultants and suppliers are usually reluctant to work on smaller projects, as it would earn them less money. Consequently, smaller companies are only marginally involved and often lag behind in their efforts to become more sustainable.

Although regulations are mostly considered as stringent, they are also perceived to have a fair level of flexibility. Stakeholders interviewed mentioned that the BCA takes feedback from industrial parties into account when updating the Green Mark scheme. However, this is less true of socio-cultural aspects (which are hardly mentioned in BCA's masterplans). For example, there is little attention to the aspect of human capital, which is related to the technology that is to be implemented. An interviewee suggested that the BCA should include this aspect in the educational programs and workshops, to foster a greater sense of team collaboration.

Recently, different government agencies joined forces to support the BCA in achieving its goals. However, these agencies do have their own agendas, which could occasionally lead to conflicting issues. For example, the Public Utilities Board has set goals to lower water consumption. This conflicts with BCA's guidelines to move towards water-cooled chiller systems, which increases water consumption in buildings using this technology. With improved communication and a more integrated policy-making approach involving all of the different government agencies, these kinds of issues can basically be addressed prior to the deployment of regulations.

\subsubsection{Informal Institutions}

In Singapore, very little support seems to come from NGOs and there is a sparse presence of community initiatives vis-à-vis green buildings. All of the interviewees agreed that from a cultural perspective, Singaporeans tend to be opposed to change. There is a generalized mindset on budgeting to only start fixing things once they are broken. This means that there is no initiative to optimize a system if its basic functionalities are perceived to be in good condition. In turn, people are typically risk-averse, and behave cautiously when deciding to adopt new technology. 
However, the BCA has taken more action to provide incentives to change these cultural norms and habits. As mentioned previously, the GBIC program addresses the risk and uncertainties related to implementing new technology. Another measure is the 'Green Mark Pearl Award', which is given to building owners who demonstrate leadership in actively engaging tenants to shape their behavior and operational practices.

In addition, different media were being used to advertise green buildings, and public engagement efforts are also being made. The 'Green School Roadmap' gives younger generations of the public first-hand experience in the green building movement. In addition, a growing number of university courses are designed and dedicated to sustainable building design and green building technology. Overall, this movement is viewed by the interviewees as gaining momentum.

A summary of the results, with respect to the four aspects of SIS, is presented in Table 1.

Table 1. Results of the analysis using the SIS concepts.

\begin{tabular}{|c|c|}
\hline SIS Component & Results \\
\hline $\begin{array}{l}\text { Technological } \\
\text { regime }\end{array}$ & $\begin{array}{l}\text { Technology: } \\
\text { - } \quad \text { Economic feasibility of green technology is improving as payback periods are reducing and people are looking } \\
\text { - } \quad \text { Risks involved in implementing new technology is unwritten by government through GBIC scheme. } \\
\text { - There is an unwillingness l of change in people's mindsets as sustainability is considered an abstract concept; } \\
\text { top-tier management staff are not interested. } \\
\text { There is no lack of technical expertise in Singapore; however, those with expertise are unable to influence mindset } \\
\text { of the public and corporate management. } \\
\text { Complementarities and interdependencies: } \\
\text { - } \quad \text { Green technology is replacing existing technology and will fully overthrow it in the near future. } \\
\text { - Both the government and the private sector are promoting the use of solar panels. } \\
\text { - There is a surge in demand for building management systems and high precious sensors due to the stringent } \\
\text { Green Mark standards. } \\
\text { Knowledge base: } \\
\text { - There is sufficient knowledge and expertise about green buildings and related technology. } \\
\text { - Knowledge is trapped within the industry, consultants and producers. } \\
\text { The Third Masterplan by the BCA seeks to educate tenants. } \\
\text { Learning process: } \\
\text { - } \quad \text { Both internal and external learning process are taking place. } \\
\text { There are many platforms to support knowledge exchange, and to disseminate knowledge from the industry } \\
\text { to consumers. }\end{array}$ \\
\hline Market demand & $\begin{array}{l}\text { Risk aversion to new technology } \\
\text { - } \quad \text { The EcoCampus project by Nanyang Technological University will serve as a test bed for new technology. } \\
\text { The BCA “BREEF" (Building Retrofit Energy Efficiency Financing) scheme will help to underwrite financial risk } \\
\text { of implementing new technology; Sustainability is still not prioritized in the offices sector. } \\
\text { - The Green Mark Portfolio Programme seeks to certify apartments to let for tenant (as opposed to entire } \\
\text { buildings); } \\
\text { The Green Lease Toolkit serves as a handbook for owners and tenants on good practices and sustainability targets. } \\
\text { There is a hesitancy to move towards energy efficient technology in retail spaces: } \\
\text { - } \quad \text { Mandating the use of double door systems to prevent energy losses } \\
\text { - } \quad \text { Mandating the use of energy efficient lighting } \\
\text { Undervaluation of green buildings: } \\
\text { - } \quad \text { The Green Mark Gross Floor Area (GM GFA) incentive scheme is implemented, in which buildings can be } \\
\text { awarded increased gross floor area when the buildings undergo substantial energy performance improvements. } \\
\text { There are evaluation meetings to increase market value of green buildings so that investors might find it } \\
\text { attractive to finance them. }\end{array}$ \\
\hline $\begin{array}{c}\text { Actors, } \\
\text { networks, } \\
\text { and interactions }\end{array}$ & $\begin{array}{l}\text { Actors: } \\
\text { - } \quad \text { A wide range of primary and secondary actors is involved. } \\
\text { Interactions and Networks: } \\
\text { - } \quad \text { Multiple platforms support stakeholder interaction through conferences, workshops, and feedback sessions } \\
\text { organized by the BCA. } \\
\text { There is much ineffective inter-stakeholder collaboration, which is related to a lack of communication and the } \\
\text { absence an integrative (multi-stakeholder) design framework to be used in projects. }\end{array}$ \\
\hline
\end{tabular}


Table 1. Cont.

\begin{tabular}{|c|c|}
\hline SIS Component & Results \\
\hline $\begin{array}{l}\text { Institutional } \\
\text { framework }\end{array}$ & $\begin{array}{l}\text { Formal institutions: } \\
\text { - There are different government policies that are moderately effective. } \\
\text { - } \quad \text { Effectiveness is mostly related to the implementation and enforcement of strict regulations. } \\
\text { - } \quad \text { A grant scheme is in place, but can be improved to (also) target small- and medium-sized companies (which have } \\
\text { poor access to capital to make investments independently). } \\
\text { - There is flexibility in policies. } \\
\text { - There are occasional conflicts between different governmental agencies involved in (different aspects) of Green } \\
\text { Building projects. } \\
\text { Informal institutions: } \\
\text { - There is little support to, and involvement of, NGO and community groups. } \\
\text { - } \quad \text { Mandatory policies are received well by target group members; voluntary schemes only reach target } \\
\text { - } \quad \text { Mroups poorly. } \\
\text { - } \quad \text { Awareness has increased, in part related to courses being taught at universities and schools. }\end{array}$ \\
\hline
\end{tabular}

\section{Discussion}

The results give the impression that the current sectoral innovation system is supportive towards Green Buildings niche formation in Singapore. The case study revealed that the national government (via the BCA) took a central role in Singapore's Green Building innovation system. This observation is in line with results from a study by Bossink [9] on innovation systems in the Dutch construction, which revealed that government took a central role with just a few specialized firms in a supporting role, and with a majority of the firms in industry acting passively. This remarkable observation is in contrast with more commonly held views by innovation scholars (e.g., [8]) who claim that commercial firms and research institutions should have the lead, with the government playing a supporting role. Other factors deemed successful concerned the government setting up a stakeholder network for interaction, and the BCA setting the conditions under which demonstration could successfully operate. In line with Bossink [10], the Singapore case study revealed that the driving of innovation by organizing inter-stakeholder interaction via networks and platforms of interaction was successful. Regarding the demonstration projects, the scheme called "BREEF" (Building Retrofit Energy Efficiency Financing) was used to reduce risk aversion among investors and project developers. This observation is in line with the results from a study [11] in which the balancing of risks was found to be a critical factor to positively influence clean technology innovation in demonstration projects. Other factors also revealed in [11], were also observed in the Singapore case study vis-à-vis the demonstration projects, viz. experiential learning by participants; having policy, regulation, and legislation in favor of innovation; market demand creation for innovative products; positive communication; technology demonstration and deployment expenditure; and the use of innovation labels.

However, there are still substantial barriers that prevent the widespread uptake. In summary, they concern: (1) inflexible habits and mindsets; (2) the main push for green buildings coming predominantly from the government; and (3) ineffective collaboration.

The barriers found in the Singapore case are not unique; they also appear in other countries. For example, the inflexible habits and mindsets of end-users lead directly to a lack of demand for green innovations in the building sector. Lack of demand was also observed in the Netherlands [21]. The hesitancy consumers had to adopt green building technology has also been observed in the US and Korea [34]. Risk aversion also played a strong role in the inflexible habits of people, as was observed in Sweden [37]. More in general, the problem seems related to the so-called "efficiency paradox" [35]. Management of real estate corporations is unwilling or simply not interested to invest in energy efficient applications, despite the evident efficiency gains that can be made (also in monetary terms). Those who have (techno-economic) expertise were found to be unable to influence and persuade decision-makers in public and corporate management.

Regarding the ineffective collaboration in Singapore, it was noticed that the different stakeholders involved in building projects had not adopted integrative design approaches. This meant that they 
usually only came together to work on a project at scattered events along the project's timeline. This led to fleeting interactions, lack of coherence, difficult collaboration patterns and in the end to sub-optimal design of Green Buildings, which was also observed by Albino and Berardi [12] and Berardi [31] in other studies. In addition, approaches to foster integrated relationships between construction stakeholders (as suggested by Berardi [31]) were often absent. It is here that room for improvement lies.

This issue points to a certain shortcoming of the SIS framework (like many other conceptual frameworks in Innovation Studies, Transition Studies, economic models, innovation-diffusion models and policy frameworks): there is a lack of attention to the temporal dimension: i.e., to configurational dynamics in construction building processes that tend to differ over time, and that have a big impact on decision-making outcomes, and adoption of innovative energy appliance, a phenomenon found in several studies addressing decision-making processes in sustainable building projects [31,32,79]. However, the temporal dimension, as a problematic factor to adoption of innovative energy options in building construction processes, has also received attention in a more conceptual and methodological way. When explaining the outcomes of projects (when compared to initial goals that were set) [31,32,80], and when addressing in policy implementation or policy monitoring and evaluation, the temporal dimension is of great importance [62].

While different countries have adopted different strategies to overcome the barriers of Green Building market development, Singapore's strategy has been moderately effective. However, when compared to some measures mentioned in the literature, it can be seen that there is potential for improvement. Two examples of propositions would be the use of tax exemptions for new residential buildings that are LEED-Silver certified, as in the city of Baltimore, US [46], and the state-owned "KfW" bank in Germany, which provides loans at reduced interest rates for buildings with higher energy performance [42]. Since green buildings are under-appreciated in Singapore, tax exemptions and reduced interest rates might help to increase their market value.

There are also other strategies that the government of Singapore can employ to tackle key barriers. One of the problems confronting green building uptake in Australia [81] was the central government's inability to model the uptake of technology, and thus predict the effectiveness of policies targeting green building market introduction. Singapore is facing a similar problem. Currently, the BCA is considering the use of the EEB Policy modeling tool. This has been successfully used in other cities across the world. It can help model the building landscape according to the exact situational conditions of the city and simulate the effects of certain policies. This, it is believed, will enhance the effectiveness of policy schemes.

In line with Gou et al. [45], the BCA is perceived to be at the forefront of the Green Buildings movement, and it is continually taking steps to improve and evolve further. The Green Mark scheme has been adopted in 71 cities. Although Singapore is performing well within Asia Pacific region, it is not performing as well as it can on a best-practice level. This is because the standards tend to be too prescriptive, rather than performance based. The performance of a building is an aggregation of the performance of its components. Interviewees thus advised that Singapore should abandon the exact stipulation of what type of technology and appliances must be used. Instead, a benchmarking system for energy performance could be considered for implementation, leaving end-users to design this for themselves, allowing for more creative solutions. Although prescriptive models are easier for authorities and developers, historically they are not progressive. More mature markets have moved away from prescriptive to performance-based models. For example, in the EU, the EPBD has adopted a performance-based model, which stipulates the performance required. Moreover, EU Member States have to try and achieve certain performance levels. With only the government pushing for green buildings in Singapore, the system becomes rigid and gives little impetus to creativity. A performance-based model could potentially encourage greater innovation from the industry and other stakeholders. 


\section{Conclusions}

This paper set out to answer the following research question: What are the benefits and limitations of Singapore's sectoral innovation system in spurring energy transition in the building sector, in particular by upscaling the use of green building technology?

The benefits of Singapore's sectoral innovation system identified concern aspects of all of the four key elements: the technological regime, market demand creation, agency, and the institutional framework. First, it was commitment by national government that set things in motion. The country's Building Construction Authority (BCA) launched the Green Mark policy scheme as an integrated strategy to spur green building innovation. In addition, many support policies were implemented and test beds were set up. A masterplan was developed to engage and educate building users, in particular tenants. Platforms were established to stimulate the exchange of best practices, expertise, and state-of-the-art knowledge. Strict regulations were issued to mandate the use of efficient equipment in new offices. In addition, Green Mark standards were developed. To attract investors, a scheme was implemented to cope with investment risks; incentive schemes and toolkits were made available, next to the government and the private sector running relevant renewable energy technology support programs of their own (e.g., solar panels). In addition, a certification scheme was developed. Finally, the schemes that were implemented were monitored, and evaluated regularly. In response, the government made sure policies remained flexible and could be adjusted in time.

As a result of this integrated approach, technical and techno-economic expertise of green buildings developed rapidly. The set of (both primary and secondary) actors involved in the green building niche increased, and so did interactions between them (e.g., facilitated by knowledge platforms), also stimulating internal and external learning processes. Furthermore, economic feasibility of green building technology improved as payback periods decreased and potential investors started to take more interest in looking for equipment with long term value. As a result, the Green Buildings niche matured, and green building technology started to gain a serious foothold in the conventional domestic building market.

Despite the benefits mentioned, the case study also revealed key barriers preventing the large-scale uptake of green building technology: (1) inflexible habits and mindsets of end-users; (2) the main push for green buildings coming predominantly from the government; and (3) ineffective inter-actor collaboration. Measures that were set in place by the government and other stakeholders to overcome these barriers were only considered moderately effective.

Despite the barriers exposed, the lessons from the Singapore case are worth disseminating to policy makers in other administrative entities who strive to green their buildings sector by adopting green buildings. Although the study presented in this paper sheds light on sectoral Green Buildings innovation in Singapore, the results should be understood with caution. Limitations of the study concern the use of a single case study design, making it hard to generalize results and to compare results with other cities and states. Moreover, the study presented was limited in terms of stakeholder representatives, i.e., by the number of interviews conducted. For future studies it would be recommended to make the study more inclusive by surveying a broader set of stakeholders, and hence presenting a wider set of perspectives. In addition, it could be valuable to explore the views, preferences and experiences vis-à-vis Green Building innovation systems with large sets of stakeholder group members. This could be studied by using quantitative surveys, which also allows for better generalization of results, than using a single case study research design only.

This paper has provided some valuable notions, particularly on the institutional dimension of the sectoral innovation system of the Singapore case (in particular Singapore's central government strategy, program, policy instruments, and certification systems used). However, it is important to note that more studies should be conducted in Singapore to gain further insights into the impact and effectiveness of policies that have been implemented, the outcomes of projects, and to map the changing dynamics of the building sector in Singapore and its influence on Green Buildings niche market formation. It is also encouraged that similar research concerning the (sectoral) innovation 
Table A1. Cont.

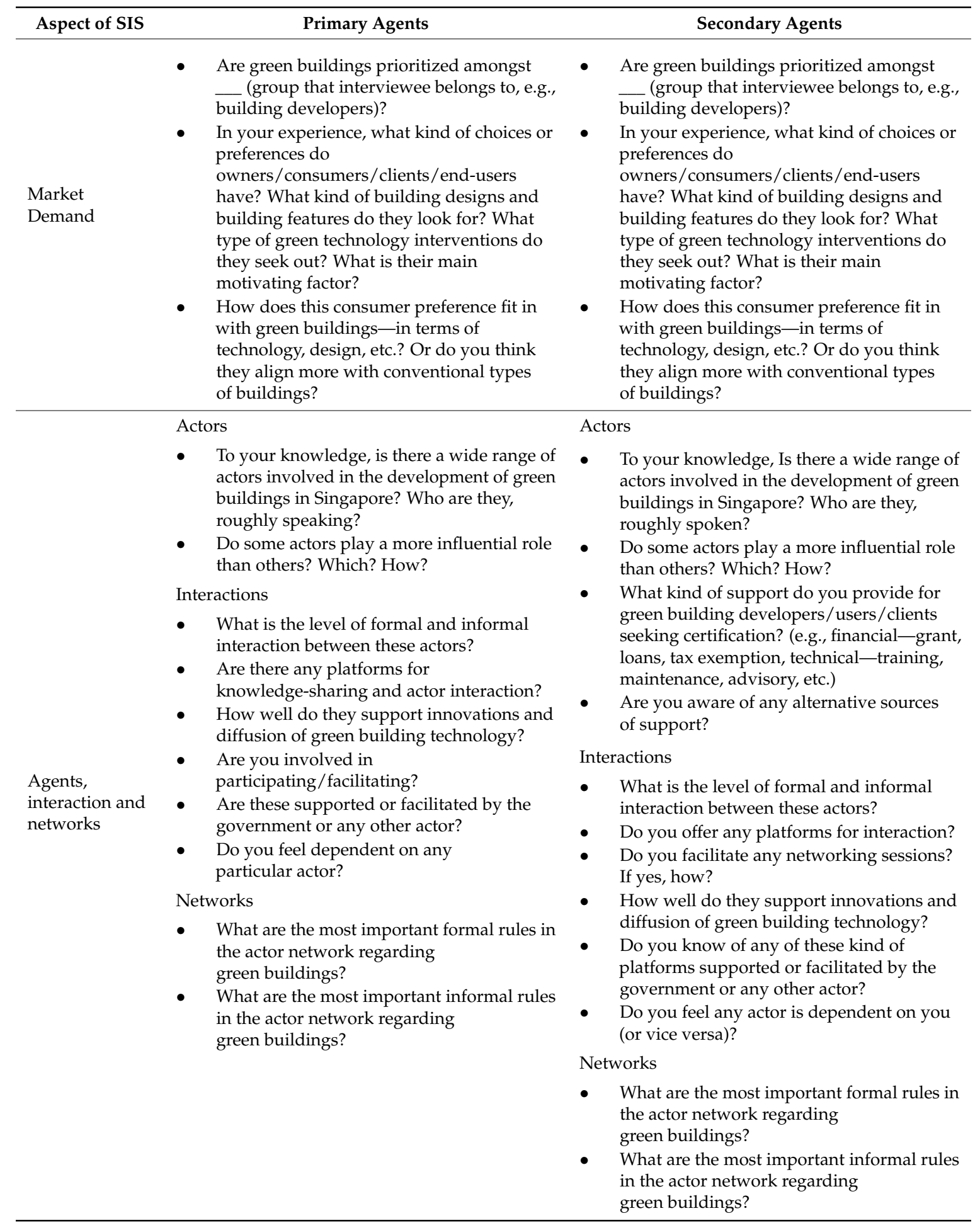


Table A1. Cont.

\begin{tabular}{|c|c|c|}
\hline Aspect of SIS & Primary Agents & Secondary Agents \\
\hline $\begin{array}{l}\text { Institutional } \\
\text { Framework }\end{array}$ & $\begin{array}{l}\text { Policy } \\
\text { - To what extent are rules, regulations, } \\
\text { policies, initiatives, and monitoring aligned } \\
\text { towards the promotion of green buildings? } \\
\text { - Is there sufficient support } \\
\text { from government? } \\
\text { Non-policy } \\
\text { - How do informal institutions (such as } \\
\text { common habits, beliefs, standards, } \\
\text { established practices, etc.) support the } \\
\text { development of green buildings? } \\
\text { How do informal institutions (such as } \\
\text { common habits, beliefs, standards, } \\
\text { established practice, etc.) inhibit } \\
\text { development of green buildings? }\end{array}$ & $\begin{array}{l}\text { Policy } \\
\text { - } \quad \text { Do you know what policy instruments are } \\
\text { currently implemented to incentivize people } \\
\text { to get their buildings certified/promote the } \\
\text { transition to green buildings in Singapore? } \\
\text { - How effective were these policies in terms } \\
\text { of stimulating green buildings innovations? } \\
\text { - What is the role of government in providing } \\
\text { support for green building developers? } \\
\text { - How stringent or flexible are } \\
\text { policies/rules/institutions towards the } \\
\text { development of green buildings? } \\
\text { Non-policy } \\
\text { - What are the non-policy tools being used? } \\
\text { (For example, knowledge sharing platforms, } \\
\text { private sector projects, NGO projects, } \\
\text { market-based certification schemes, } \\
\text { competitions, community projects, etc.). } \\
\text { What is your role in these non-policy } \\
\text { mechanisms of promoting green buildings } \\
\text { in Singapore? }\end{array}$ \\
\hline
\end{tabular}

\section{References}

1. EIA. U.S. Energy Information Administration-EIA-Independent Statistics and Analysis; U.S. Energy Information Administration-EIA: Washington, DC, USA, 2013.

2. Bank, W. Urban Population (\% of total); World Bank: Washington, DC, USA, 2013.

3. BCA. BCA Building Energy Benchmarking Report 2014; Building Construction Agency: Singapore, 2014.

4. BCA. Annual Report 2012: Redefining the Built Environment and Industry; Building Construction Authority: Singapore, 2013.

5. BCA. Build Green, 2015. Available online: https://www.bca.gov.sg/Publications/BuildGreen/others/ BGreen_7_2015.pdf (accessed on 19 May 2017).

6. Howe, J.C. Overview of Green Buildings. Available online: https://sallan.org/pdf-docs/CHOWE_ GreenBuildLaw.pdf (accessed on 19 May 2017).

7. BCA. Singapore: Leading the Way of Green Buildings in the Tropics; Building Construction Authority: Singapore, 2013.

8. Bartholomew, S. National systems of biotechnology innovation: Complex interdependence in the global system. J. Int. Bus. Stud. 1997, 28, 241-266. [CrossRef]

9. Bossink, B.A. Assessment of a national system of sustainable innovation in residential construction: A case study from The Netherlands. Int. J. Environ. Technol. Manag. 2009, 10, 371-381. [CrossRef]

10. Bossink, B.A. Managing drivers of innovation in construction networks. J. Constr. Eng. Manag. 2004, 130, 337-345. [CrossRef]

11. Bossink, B.A. Demonstration projects for diffusion of clean technological innovation: A review. Clean Technol. Environ. Policy 2015, 17, 1409-1427. [CrossRef]

12. Albino, V.; Berardi, U. Green buildings and organizational changes in Italian case studies. Bus. Strategy Environ. 2012, 21, 387-400. [CrossRef]

13. Butera, F.M. Climatic change and the built environment. Adv. Build. Energy Res. 2010, 4, 45-75. [CrossRef]

14. Xu, L.; Zhou, B.; Wang, C. Research on Design Technology of Green Building for Environmental Protection. Available online: https://www.google.com/url?sa=t\&rct=j\&q=\&esrc=s\&source=web\&cd=1\&ved= 0ahUKEwiyrdDM34fUAhWQJFAKHSSoB74QFggiMAA\&url=http $\% 3 \mathrm{~A} \% 2 \mathrm{~F} \% 2 \mathrm{Fwww}$.atlantis-press.com $\%$ 2Fphp\%2Fdownload_paper.php\%3Fid\%3D18006\&usg=AFQjCNH5YrueJlza1iIFbq9coaMKUvpjBw\&cad= rjt (accessed on 19 May 2017). 
15. Svenfelt, Å.; Engström, R.; Svane, Ö. Decreasing energy use in buildings by 50\% by 2050—A backcasting study using stakeholder groups. Technol. Forecast. Soc. Chang. 2011, 78, 785-796. [CrossRef]

16. Ries, R.; Bilec, M.M.; Gokhan, N.M.; Needy, K.L. The economic benefits of green buildings: A comprehensive case study. Eng. Econ. 2006, 51, 259-295. [CrossRef]

17. Von Paumgartten, P. The business case for high performance green buildings: Sustainability and its financial impact. J. Facil. Manag. 2003, 2, 26-34. [CrossRef]

18. Heerwagen, J.; Zagreus, L. The Human Factors of Sustainable Building Design: Post Occupancy Evaluation of the Philip Merrill Environmental Center; The Center for the Built Environment: Berkeley, CA, USA, 2005.

19. Hoffman, J.A.; Henn, R. Overcoming the social and psychological barriers to green building. Organ. Environ. 2008, 21, 390-419. [CrossRef]

20. Vermeulen, W.J.; Hovens, J. Competing explanations for adopting energy innovations for new office buildings. Energy Policy 2006, 34, 2719-2735. [CrossRef]

21. Faber, A.; Hoppe, T. Co-constructing a sustainable built environment in the Netherlands-Dynamics and opportunities in an environmental sectoral innovation system. Energy Policy 2013, 52, 628-638. [CrossRef]

22. Darko, A.; Chan, A.P. Review of Barriers to Green Building Adoption. Sustain. Dev. 2016. [CrossRef]

23. Zuo, J.; Zhao, Z.-Y. Green building research-current status and future agenda: A review. Renew. Sustain. Energy Rev. 2014, 30, 271-281. [CrossRef]

24. Hwang, G.B.; Tan, J.S. Green building project management: Obstacles and solutions for sustainable development. Sustain. Dev. 2012, 20, 335-349. [CrossRef]

25. Häkkinen, T.; Belloni, K. Barriers and drivers for sustainable building. Build. Res. Inf. 2011, 39, $239-255$. [CrossRef]

26. Gluch, P. Building Green-Perspectives on Environmental Mangagement in Construction. Ph.D. Thesis, Chalmers University of Technology, Gothenburg, Sweden, June 2005.

27. Pinkse, J.; Dommisse, M. Overcoming barriers to sustainability: An explanation of residential builders' reluctance to adopt clean technologies. Bus. Strategy Environ. 2009, 18, 515-527. [CrossRef]

28. Shields, R.; Manseau, A. Building Tomorrow: Innovation in Construction and Engineering; Ashgate: Aldershot Hants, UK, 2005.

29. Williams, K.; Dair, C. What is stopping sustainable building in England? Barriers experienced by stakeholders in delivering sustainable developments. Sustain. Dev. Bradf. 2007, 15, 135.

30. Anumba, C.; Ren, Z.; Ugwu, O. Agents and Multi-Agent Systems in Construction; Routledge: Abingdon, UK, 2007.

31. Berardi, U. Stakeholders' Influence on the adoption of energy-saving technologies in Italian homes. Energy Policy 2013, 60, 520-530. [CrossRef]

32. Hoppe, T. Adoption of Innovative Energy Systems in Social Housing; Lessons from eight Large-Scale Renovation Projects in the Netherlands. Energy Policy 2012, 51, 791-801. [CrossRef]

33. Howarth, B.R.; Andersson, B. Market barriers to energy efficiency. Energy Econ. 1993, 15, 262-272. [CrossRef]

34. Son, H.; Kim, C.; Chong, W.K.; Chou, J.S. Implementing sustainable development in the construction industry: Constructors' perspectives in the US and Korea. Sustain. Dev. 2011, 19, 337-347. [CrossRef]

35. DeCanio, S.J. The efficiency paradox: Bureaucratic and organizational barriers to profitable energy-saving investments. Energy Policy 1998, 26, 441-454. [CrossRef]

36. SEA. Electricity Supply and Use 2001-2014 (GWh). Statistics Sweden; Swedish Energy Agency: Stockholm, Sweden, 2015.

37. Persson, J.; Grönkvist, S. Drivers for and barriers to low-energy buildings in Sweden. J. Clean. Prod. 2015, 109, 296-304. [CrossRef]

38. Techato, K.-A.; Watts, D.J.; Chaiprapat, S. Life cycle analysis of retrofitting with high energy efficiency air-conditioner and fluorescent lamp in existing buildings. Energy Policy 2009, 37, 318-325. [CrossRef]

39. Menassa, C.C. Evaluating sustainable retrofits in existing buildings under uncertainty. Energy Build. 2011, 43, 3576-3583. [CrossRef]

40. Ascione, F.; Bianco, N.; De Masi, R.F.; de'Rossi, F.; Vanoli, G.P. Energy retrofit of an educational building in the ancient center of Benevento. Feasibility study of energy savings and respect of the historical value. Energy Build. 2015, 95, 172-183. 
41. Nelson, A.J.; Rakau, O.; Dörrenberg, P. Green Buildings: A Niche Becomes Mainstream. Available online: https://www.dbresearch.com/PROD/DBR_INTERNET_EN-PROD/PROD0000000000256216.pdf (accessed on 19 May 2017).

42. Schröder, M.; Ekins, P.; Power, A.; Zulauf, M.; Lowe, R. The KFW Experience in the Reduction of Energy Use in and CO2 Emissions from Buildings: Operation, Impacts and Lessons for the UK. Available online: https:/ /www.igbc.ie/wp-content/uploads/2015/02/KfWFullReport.pdf (accessed on 19 May 2017).

43. Shen, L.; He, B.; Jiao, L.; Zhang, X. Research on the development of main policy instruments for improving building energy-efficiency. J. Clean. Prod. 2016, 112, 1789-1803. [CrossRef]

44. Huang, B.; Mauerhofer, V.; Geng, Y. Analysis of existing building energy saving policies in Japan and China. J. Clean. Prod. 2016, 112, 1510-1518. [CrossRef]

45. Gou, Z.; Lau, S.S.-Y.; Prasad, D. Market readiness and policy implications for green buildings: Case study from Hong Kong. Coll. Publ. 2013, 8, 162-173. [CrossRef]

46. Pippin, A.M. Survey of Local Government Green Building Incentive Programs for Private Development. Available online: http:/ / digitalcommons.law.uga.edu/cgi/viewcontent.cgi?article=1010\&context=landuse (accessed on 19 May 2017).

47. BCA. BCA Green Mark Assessment Criteria and Online Application; Building Construction Agency: Singapore, 2015.

48. BCA. 3rd Green Building Masterplan; Building Construction Agency: Singapore, 2014.

49. Deng, Y.; Li, Z.; Quigley, J.M. Economic returns to energy-efficient investments in the housing market: Evidence from Singapore. Reg. Sci. Urban Econ. 2012, 42, 506-515. [CrossRef]

50. Li, Y.Y.; Chen, P.-H.; Chew, D.A.S.; Teo, C.C. Exploration of critical resources and capabilities of design firms for delivering green building projects: Empirical studies in Singapore. Habitat Int. 2014, 41, 229-235. [CrossRef]

51. Rogers, E.M. Diffusion of Innovations, 5th Revised Edition; Simon \& Schuster Ltd.: New York, NY, USA, 2003.

52. Dieperink, C.; Brand, I.; Vermeulen, W. Diffusion of energy-saving innovations in industry and the built environment: Dutch studies as inputs for a more integrated analytical framework. Energy Policy 2004, 32, 773-784. [CrossRef]

53. Geels, F. Technological transitions as evolutionary reconfiguration processes: A multi-level perspective and a case-study. Res. Policy 2002, 31, 1257-1274. [CrossRef]

54. Raven, R.; van den Bosch, S.; Weterings, R. Transitions and strategic niche management: Towards a competence kit for practitioners. Int. J. Technol. Manag. 2010, 51, 57-74. [CrossRef]

55. Raven, R. Strategic Niche Management for Biomass; Technical University Eindhoven (TU/E): Eindhoven, The Netherlands, 2005.

56. Hoogma, R. Experimenting for Sustainable Transport: The Approach of Strategic Niche Management; Taylor \& Francis: London, UK, 2002.

57. Kemp, R.; Schot, J.; Hoogma, R. Regime shifts to sustainability through processes of niche formation: The approach of strategic niche management. Technol. Anal. Strateg. Manag. 1998, 10, 175-198. [CrossRef]

58. Markard, J.; Raven, R.; Truffer, B. Sustainability transitions: An emerging field of research and its prospects. Res. Policy 2012, 41, 955-967. [CrossRef]

59. Markard, J.; Truffer, B. Technological innovation systems and the multi-level perspective: Towards an integrated framework. Res. Policy 2008, 37, 596-615. [CrossRef]

60. Murphy, L.; Meijer, F.; Visscher, H. A qualitative evaluation of policy instruments used to improve energy performance of existing private dwellings in the Netherlands. Energy Policy 2012, 45, 459-468. [CrossRef]

61. Tambach, M.; Visscher, H. Towards Energy-neutral New Housing Developments. Municipal Climate Governance in The Netherlands. Eur. Plan. Stud. 2012, 20, 111-130.

62. Hoppe, T.; Coenen, F.; van den Berg, M. Illustrating the use of concepts from the discipline of policy studies in energy research: An explorative literature review. Energy Res. Soc. Sci. 2016, 21, 12-32. [CrossRef]

63. Malerba, F. Sectoral Systems of Innovation: Concepts, Issues and Analyses of Six Major Sectors in Europe; Cambridge University Press: Cambridge, UK, 2004.

64. Malerba, F. Sectoral systems of innovation and production. Res. Policy 2002, 31, 247-264. [CrossRef]

65. Jain, M.; Hoppe, T.; Bressers, H. Analyzing Sectoral niche formation: The case of Net-Zero Energy Buildings in India. Environ. Innov. Soc. Transit. 2016, in press. [CrossRef]

66. Edquist, C. Systems of innovation: Perspectives and challenges. Afr. J. Sci. Technol. Innov. Dev. 2011, 2, $14-43$. 
67. Malerba, F. Sectoral Systems, The Oxford Handbook of Innovation; Oxford University Press: Oxford, UK, 2005; pp. 380-406.

68. Dosi, G. Technological paradigms and technological trajectories: A suggested interpretation of the determinants and directions of technical change. Res. Policy 1982, 11, 147-162. [CrossRef]

69. Nelson, R.R.; Winter, S.G. An Evolutionary Theory of Economic Change; Harvard University Press: Cambridge, MA, USA, 2009.

70. Malerba, F.; Orsenigo, L. Technological regimes and sectoral patterns of innovative activities. Ind. Corp. Chang. 1997, 6, 83-118. [CrossRef]

71. Yin, R. Case Study Research; Design and Methods; Sage Publications: London, UK, 2003.

72. Gerring, J. Case Study Research. Principles and Practices; Cambridge University Press: Cambridge, UK, 2007.

73. World Business Council for Sustainable Development. Energy Efficiency in Buildings: Business Realities and Opportunities; World Business Council for Sustainable Development Geneva: Geneva, Switzerland, 2007.

74. Mulchand, A. S'pore has world's largest district cooling plant. In The Traits Times; Asia One; Singapore Press Holdings Ltd.: Singapore, 2013.

75. Othman, L. World's biggest underground district cooling network now at Marina Bay. Today, 31 May 2017.

76. Johnston, J.G. Singapore Reaches Retail Grid Parity For Solar. The 9 Billion, 2012. Available online: http:/ / www.the9billion.com/2012/10/24/singapore-reaches-retail-grid-parity-for-solar/ (accessed on 19 May 2017).

77. Siau, M.E. HDB ramps up solar leasing with latest tender. In Today Singapore; Media Corp Press: Singapore, 2014.

78. NLB. Singapore Standards; National Library Board: Singapore, 2011.

79. Hoppe, T.; Bressers, H.; Lulofs, K. Energy conservation in Dutch housing renovation projects. In The Social and Behavioural Aspects of Climate Change; Martens, P., Ting Chiang, C., Eds.; Greenleaf: Sheffield, UK, 2010; pp. 68-95.

80. Hoppe, T.; Bressers, J.T.A.; Lulofs, K.R.D. Local government influence on energy conservation ambitions in existing housing sites-Plucking the low-hanging fruit? Energy Policy 2011, 39, 916-925. [CrossRef]

81. Higgins, A.; Syme, M.; McGregor, J.; Marquez, L.; Seo, S. Forecasting uptake of retrofit packages in office building stock under government incentives. Energy Policy 2014, 65, 501-511. [CrossRef] 